\title{
PENERAPAN KONSEP SUNK COST TERHADAP KEPUTUSAN PENGGANTIAN MESIN FOTOKOPI PADA TOKO GIRSA
}

\author{
Oleh:
Andrea Giovani Sirang ${ }^{1}$
Lidia Mawikere ${ }^{3}$ \\ David Paul Elia Saerang ${ }^{2}$ \\ Fakultas Ekonomi dan Bisnis \\ Universitas Sam Ratulangi Manado \\ email: ${ }^{1}$ sirangandrea@yahoo.com
}

\begin{abstract}
Many methods of costs incurred to assist managers in making decisions. One of the so-called sunk costs, Sunk costs are costs incurred in the past and can not be changed now and in the future. Sunk costs often affect a company manager's decision to take the right decision. One was the decision in terms of financing fixed assets owned by the company.

This research was conducted at Toko Girsa which is located in R.W. Monginsidi Road 49, Manado. The object of this is enelitian fixed assets such as machinery fotocopy Canon IR 6070 owned company. The purpose of this study was to determine the application of the concept of sunk costs and influence in decision making purchases of fixed assets at Toko Girsa.

The method used in this research is descriptive method is a method that collects, formulate and classify and interpret the data obtained by the analysis of quantitative data presented in the form of numbers that are related to sunk costs arising from the financing of fixed assets. The results showed that the sunk costs can not be used as a basis for making the right decisions for the management, including fixed asset purchase decision.
\end{abstract}

Keywords: sunk cost, decision purchasing, fixed assets.

\section{PENDAHULUAN}

\section{Latar Belakang}

Dewasa ini, sudah semakin banyak perusahaan yang bergerak di berbagai bidang, salah satunya adalah percetakan. Tujuan dari kebanyakan perusahaan adalah untuk memaksimumkan laba atau keuntungan. Untuk dapat mencapainya, banyak cara yang perusahaan lakukan seperti memaksimalkan input perusahaan agar menghasilkan output yang bernilai, ataupun pemilihan lokasi yang strategic demi kelagsungan usahanya. Karna posisi yang strategic, akan menghasilkan konsumen yang banyak.

Di era modern sekarang ini, daya saing antar tiap-tiap perusahaan semakin kuat. Untuk itu diperlukan strategi tersendiri dari tiap-tiap perusahaan agar perusahaannya tetap going concern. Peningkatan kualitas adalah cara yang paling sering dilakukan untuk menarik minat konsumennya. Tetapi, menghasilkan output yang berkualitas dengan harga yang murah, merupakan hal yang tidak mudah dilakukan. Untuk itu dibutuhkan kemampuan dari pihak manajemen memaksimalkan semua input perusahaan, agar dapat menghasilkan outut yang berkualitas. Selain itu, pihak manajemen juga harus menjaga kestbilan dan eksistensi perusahaan agar tetap hidup dengan cara memprediksi kondisi dari usaha-usaha yang dilakukan pada masa yang akan datang yang penuh dengan ketidakpastian, serta mengamati faktor-faktor yang dapat mempengaruhi laba perusahannya. 
Perusahaan harus lebih eektif dan efisien dalam menyikapi langkah yang akan diambil olaeh manajemen, dimuliai dari proses kerja manajemen, yaitu perencanaan strategi, perancangan suatu sistem, pengukuran bahan baku, pengkuran kinerja karyawan, pengawasan suatu system, penerapan strategi dan pelayanan terhadap konsemen. Untuk menjlankan strategi dan pengambilan keputusan yang tepat oleh manajemen, dbutuhkan peranan dari ilmu akuntansi yang dapat memberikan informasi tentang keadaan perusahaan secara akurat. Peran akuntan sangatlah penting dalam memberikan informasi kondisi perusahaannya, terlebih khusus informasi keuangan. Kondisi keuangan sebuah perusahaan akan terlihat jelas pada laporan keuangannya, yang pastinya dibuat oleh seorang akuntan. Dari laporan keuangan tersebutn dapat dilihat bahwa sebuah perusahaan mengalami keuntugan ataupun kerugian. Tidaklah menjadi masalah jika sebuah perusahaan mengalami keuntungan, tetapi akan menjadi masalah jika perusahaan mengalami kerugian. Banyak hal yang dapat menyebabkan perusahaan menjadi rugi, salah satunya adalah biaya dan beban yang dihasilkan perusahaan terlalu besar. Dalam ilmu Akuntansi Biaya, seorang akuntan dapat mengukur dan menganalisa biaya yang dihasilkan oleh perusahaan.

Biaya pada umumnya menjadi salah satu landasan keputusan dalam suatu perencanaan dan pengambilan keputusan, berbeda dengan beban yang hanya mempunyai manfaat dalam mencapai suatu tujuan. Biaya menurut Prawinegoro dan Purwanti (2009) dalam Nilisye Ratag (2013), menyatakan bahwa biaya adalah kas dan setara kas yang dikorbankan untuk memproduksi atau memperoleh barang atau jasa yang diharapkan akan memperoleh manfaat atau keuntungan dimasa mendatang. Simamora (2012:40) menyatakan bahwa biaya adalah kas atau nilai setara kas yang dikorbankan (dibayarkan) untuk barang atau jasa yang diharapkan memberikan manfaat (pendapatan) pada saat ini atau di masa mendatang bagi perusahaan.

Sunk cost dalam bahasa Indonesia adalah biaya terpendam, biaya tertanam, biaya tenggelam dan beberapa arti lain. Secara ekonomi sunk cost adalah jenis biaya yang berhubungan dengan pengambilan keputusan. Sunk cost adalah salah satu jenis biaya yang di kenal dan diakui di dunia ekonomi. Kamus akuntansi sunk cost adalah biaya yang timbul pada masa lalu yang tidak akan terpengaruh pengambilan keputusan pada saat ini, Siegel \& Shim. (2000). Menurut Krismiaji dan Aryani (2011 : 32) Biaya masa lalu (Sunk cost) adalah biaya yang sudah terjadi di masa lalu dan tidak dapat diubah sekarang maupun di masa mendatang. Karena biaya ini tidak dapat diubah oleh keputusan sekarang maupun keputusan di masa mendatang, maka biaya ini bukan merupakan biaya diferensial

Toko Girsa adalah perusahaan yang bergerak dalam bidang print dan fotokopi. Di situ terdapat 8 buah mesin yang tiap hari beoperasi. Dalam 1 hari, Toko Girsa dapat menghasilkan kurang lebih 10.000 lembar copy-an. Jadi setiap hari, 1 buah mesin kira-kira meng-copy sebanyak 1.250 lembar. Dengan begitu, perawatannya pun harus dilakukan dengan rutin, baik itu penggantian suku cadang, atau dig anti dengan mesin yang baru, agar perusahaan dapat mendapatkan keuntungan maksimal setiap harinya. Mesin-mesin tersebut dapat di hitung biaya terpendamnya atau sunk cost, yang dapat mebantu pemilik perusahaan untuk mengambi keputusan dalam menentukan apakah suatu mesin mesin yang lama lebih efisien diganti dengan mesin yang baru, ataukah malah masih bisa diperbaiki.

\section{Tujuan Penelitian}

Tujuan penelitian ini adalah untuk mengetahui penerapan konsep sunk cost dan pengaruhnya pada perusahaan dalam pengambilan keputusan pembelian aktiva tetap.

\section{TINJAUAN PUSTAKA}

\section{Akuntansi}

Menurut Mulyadi (2011 : 1) Akuntansi dapat dipandang sebagai suatu system yang mengelolah masukan berupa data operasi dan data keuangan untuk menghasilkan keluaran berupa data operasi dan data keuangan untuk menghasilkan keluaran berupa informasi akuntansi yang dibutuhkan oleh pemakai. Menurut L.M Samryn (2012 : 4) mendefinisikan akuntansi sebagai suatu proses identifikasi, pegukuran dan pengkomunikasian informasi ekonomi yang menghasilkan informasi yang berguna bagipembuatan kebijakan dan keputusan oleh pemakainya. 
Definisi bebas dari akuntansi menurut Wasilah dan Nuryanti (2014 : 2) adalah identifikasi Transaksi yang kemudian diikuti dengan kegiatan pencatatan penggolongan serta pengikhtisarian transaksi tersebut sehingga menghasilkan laporan keuangan yang dapat digunakan untuk pengambilan keputusan.

\section{Akuntansi Manajemen}

Akuntansi manajemen dapat dipandang dari dua sudut : akuntansi manajemen sebagai salah satu tipe akuntansi dan akuntansi manajemen sebgai salah satu tipe informasi. Sebagai salah satu tipe akuntansi, akuntansi manajemen merupakan suatu system pengelolahan informasi keuangan yang digunakan untuk menghasilkan informasi keuangan bagi kepentingan pemakain intern organisasi. Akuntansi manajemen merupakan salaha satu tipe akuntansi di anatara dua tipe akuntansi : akauntansi keuangan dan akuntansi manajemen. Sebagai salah satu tipe informasi, akuntansi manajemen merupakan tipe informasi kuantitatif yang menggunakan uang sebagai satuan ukuran, ynag digunakan untuk membantu manajemen dalam pelaksanaan pengeloalaan perusahaan. Akuntansi manajemen adalah informasi keuangan yang merupakan keluaran yang dihasilkan oleh tipe akuntansi manajemen, yang dimanfaatkan terutama oleh tipe akuntansi manajemen, yang dimanfaatkan terutama oleh pemakiai intern organisasi, Mulyadi (2011:2)

Adapun pengertian Akuntansi Manajemen menurut para ahli, yaitu :

Simamora (2012:13), menyatakan bahwa akuntansi manajemen adalah proses pengidentifikasian, pengukuran, penghimpun, penganalisian, penyusunan, penafsiran dan pengkomunikasian informaasi keuangan yang digunakan oleh manajemen untuk merencanakan, mengevaluasi, dan mengendalikan kegiatan usaha didalam sebuah organisasi,serta untuk memastikan penggunaan dan akuntabilitas sumber daya yang tepat. Halim, Bambang dan Kusufi (2013:3), menyatakan bahwa Akuntansi Manajemen adalah "Suatu kegiatan (proses) yang menghasilkan informasi keuangan bagi manajemen untuk pengambilan keputusan ekonomi dalam melaksanakan fungsi manajemen. Samryn (2012 : 4) Akuntansi Manajemen merupakan bidang akuntansi yang berfokus pada penyediaan, termasuk pengembangan dan penafsiran informasi akuntansi bagipara manajer untuk digunakan sebagai bahan perencanaan, pengendalian operasi dan dalam pengambilan keputusan.

Biaya

Biaya merupakan pengorbanan yang di lakukan untuk mencapai suatu tujuan dan menjadi manfaat di masa yang akan datang. Khususnya di dalam suatu organisasi atau perusahaan, biaya biasa digunakan sebagai penentuan harga barang, pengendalian internal, dan sebagai informasi untuk pihak eksternal. Berikut ini adalah pengertian biaya menurut beberapa ahli, yaitu :

Simamora (2012:40) menyatakan bahwa biaya adalah kas atau nilai setara kas yang dikorbankan (dibayarkan) untuk barang atau jasa yang diharapkan memberikan manfaat (pendapatan) pada saat ini atau di masa mendatang bagi perusahaan. Menurut Anwar, Chairul, dkk (2010) Biaya merupakan sejumlah uang yang dikeluarkan (atau dapat berbentuk hutang) untuk kegiatan operasi perusahaan dalam rangka menghasilkan barang barang atau jasa - jasa. Beban (expenses ) adalah penurunan manfaat ekonomi selama suatu periode akuntansi dalam bentuk arus keluar atau berkurangnya aktiva atau terjadinya kewajiban yang mengakibatkan penurunan equitas yang tidak menyangkut pembagian kepada penanam modal.

\section{Akuntansi Biaya}

Mulyadi (2014 : 7) mengatakan bahwa akuntansi biaya mempunyai tiga tujuan pokok : penentuan kos produk, pengendalian biaya dan pengambilan keputusan khusus. Untuk memenuhi tujuan penentuan kos produk, akauntansi biaya mencatat, menggologkan, dan meringkas biaya-biaya pembuatan produk atau penyerahan jasa. Biaya yang dikumpulkan dan disajikan adalah biaya yang telah terjadi di masa lalu atau biaya historis. Selanjutnya pengendalian biaya harus didahuli dengan penentuan biaya yang seharusnya dikeluatkan untuk memproduksi satu satuan produk. Jika biaya yang seharusnya ini telah diterapkan, akuntansi biaya bertugas untuk memantau apakah pengeluaran biayan yangsesungguhnya sesuai dengan 
biaya yang seharusnya tersebut. Kemudian pengambilan keputusn khusus menyangkut masa yang akan datang. Oleh karena itu informasi yang relevan dengan pengambilan keputusan khusus selalu berhubungan dengan informasi masa yang akan datang.

\section{Sunk Cost}

Sunk cost dalam bahasa Indonesia adalah biaya terpendam, biaya tertanam, biaya tenggelam dan beberapa arti lain. Secara ekonomi sunk cost adalah jenis biaya yang berhubungan dengan pengambilan keputusan. Sunk cost adalah salah satu jenis biaya yang di kenal dan diakui di dunia ekonomi. Kamus akuntansi sunk cost adalah biaya yang timbul pada masa lalu yang tidak akan terpengaruh pengambilan keputusan pada saat ini, Siegel \& Shim. (2000).

Menurut Krismiaji dan Aryani (2011 : 32) Biaya masa lalu (Sunk cost) adalah biaya yang sudah terjadi di masa lalu dan tidak dapat diubah sekarang maupun di masa mendatang. Karena biaya ini tidak dapat diubah oleh keputusan sekarang maupun keputusan di masa mendatang, maka biaya ini bukan merupakan biaya diferensial.

Adapun hubungan sunk cost (biaya depresiasi) dengan biaya diferensial menurut Devi (2012 : 7), depresiasi merupakan alokasi secara periodic harga pokok aktiva yang tetap diperoleh pada waktu yang lampau. Depresiasi berasal dari keputusan penanaman modal telah dilaksanakan dan aktiva tetap telah dibeli, biaya depresiasi yang kemudian jadi ditentukan dengan mempertimbangkan umur ekonomis aktiva tetap tersebut dan metode depresiasi yang dipilih oleh manajemen. Depresiasi berhubungan erat dengan pengambilan keputusan jangka panjang dan hanya dipengaruhi pada saat penanaman modal di ambil. Dalam keputusan jangka pendek biaya depresiasi bukan merupakan biaya diferensial dan dapat diabaikan. Biaya - biaya depresiasi, deplesi dan amortisasi merupakan biaya terbenam (sunk cost) dan bukan biaya diferensial dalam pengambilan keputusan jangka pendek.

\section{Penelitian Terdahulu}

1. Garland (1990) dengan penelitian mengenai Throwing Good Money After Bad: The Effect of Sunk Cost on the Decision to Escalate Commitment to an Ongoing project yang bertujuan untuk menganalisa efek dari Sunk Cost yang menyebabkan manajer tetap melanjutkan proyek. Penelitian yang dilakukan menggunakan metode penelitian analisis varian, yang menunjukkan bahwa manajer cendenrung mengambil keputusan untuk tetap melanjutkan proyek yang gagal meskipun mengalami kerugian dikarenakan terjebak dalam konsep sunk cost fallacy. Terdapat persamaan dengan penelitian ini yakni terletak pada keputusan seorang manajer terhadap penerapan konsep Sunk Cost, sedangkan perbedaan terletak pada metode analisis dimana metode yang digunakan adalah metode deskriptif.

2. Hutzel (2000) dengan penelitian mengenai The Role of Probability of success Estimatesin the Sunk Cost Efect yang bertujuan untuk mengetahui peran sunk cost dalam suatu kesuksesan. Penelitian yang dilakukan menggunakan metode penelitian deskriptif, yang menunjukkan bahwa dalam situasi yang melibatkan sunk cost masyarakat sebaiknya tidak mengharapkan nilai atau mengharapkan kegunaan dari pembuat keputusan. Terdapat persamaan dengan penelitian ini yakni terletak pada penelitian menyangkut sifat Sunk Cost, sedangkan perbedaan terletak pada data yang diperoleh data kuantitatif.

3. Hayne \& Thompson (2011) dengan penelitian mengenai Entry and Exit Behavior in the Absence of Sunk Costs: Evidence from a Price Comparasion Site yang bertujuan untuk menganalisa perilaku sunk cost terhadap barang di pasar memakai metode perbandingan dimana partisipasi sunk costs tidak diperlukan. Penelitian yang dilakukan menggunakan metode penelitian analisis perbandingan dan analisis varian, yang menunjukkan bahwa tidak adanya peran sunk cost akan mempercepat aliran bersih (Net Flow) penjual antara metode perbandingan dan pendatang potensial. Terdapat persamaan dengan penelitian ini yakni terletak pada keputusan seorang manajer terhdap penerapan konsep Sunk Cost, sedangkan perbedaan terletak pada metode analisis dimana metode yang digunakan adalah metode deskriptif. 


\section{METODE PENELITIAN}

\section{Jenis dan Sumber Data}

\section{Jenis Data}

a. Data kualitatif adalah data yang disajikan dalam bentuk kata-kata yang mengandung makna dan tidak dapat dikuantitatifkan. Jenis data seperti ini berupa sejarah singkat perusahaan, struktur organisasi, pemeliharaan mesin dan informasi lainnya yang relevan dengan penulisan ini.

b. Data kuantitatif adalah data yang berupa angka-angka. Jenis data seperti ini berupa data yang berhubungan dengan penerapan konsep sunk cost yang contohnya seperti selisih harga beli dan harga jual sebuah mesin, nilai masa pakai suatu kendaraan.

\section{Sumber Data}

a. Data primer adalah data yang langsung dikumpulkan leh peneliti (atau petugas-petugasnya) dari sumber pertamanya)

b. Data sekunder itu biasanya telah tersusun dalam bentuk dokumen-dokumen. Misalnya data mengenai produktivitas suatu perguruan tinggi, data mengenai persediaan pangan di suatu daerah dan sebagainya.

\section{Metode Pengumpulan Data}

Metode pengumpulan data yang digunakan adalah sebagai berikut:

\section{Penelitian Lapangan (Field Research)}

Suatu metode pengumpulan data yang dilakukan dengan mengamati secara langsung objek penelitian yang diteliti dengan cara:

a. Observasi, yaitu pengumpulan data yang dilakukan dengan mengadakan pengamatan secara langsung ke obyek penelitian, tepatnya pada Toko Girsa.

b. Interview, yaitu bentuk pengumpulan data yang dilakukan dengan mengadakan wawancara atau tatap muka secara langsung dengan pimpinan perusahaan atau karyawan yang ada kaitannya dengan penelitian yang akan dibahas.

c. Dokumentasi yaitu penelitian yang dilakukan dengan jalan mengumpulkan dokumen-dokumen perusahaan yang ada kaitannya dengan penelitian yang akan dibahas.

\section{Tinjauan Kepustakaan}

Bentuk pengumpulan data yang dilakukan dengan mempelajari literatur-literatur, karya-karya ilmiah serta bacaan-bacaan lain yang berkaitan dengan penulisan.

\section{Metode Analisis Data}

Metode analisis data yang digunakan adalah metode deskriptif kuantitatif dalam hal ini penelitian bersifat sistematis, terencana, dan terstruktur sejak awal penelitian dan hasil akhir akan berupa angka-angka objektif. Dalam penelitian ini, metode akan diterapkan untuk menguraikan atau menggambarkan keputusan pembelian aktiva tetap dengan menggunakan metode sunk cost pada Toko Girsa. Metode sunk cost adalah jenis biaya yang berhubungan dengan pengambilan keputusan.

\section{HASIL PENELITIAN DAN PEMBAHASAN}

\section{Hasil Penelitian}

Toko Girsa didirikan oleh Bapak Tonny Tendean pada tahun 2001 yang bertempat jln. R.W. Monginsidi no 49. Bapak Tonny Tendean ini adalah pemilik tunggal dari Toko Girsa. Pada awalnya Toko Girsa menawarkan jasa fotocopy. Namun pada tahun 2005 usaha ini berkembang menjadi usaha yang menawarkan jasa yang lain seperti printing, cetak baliho, brosur dan jilid buku. Pada saat ini Toko Girsa sudah sangat terkenal, terlebih di kalangan 
Mahasiswa Universitas Sam Ratulangi. Karena posisinya berdekatan dengan daerah kampus, jadi sebagian besar pelanggannya adalah mahasiswa. Tetapi bukan karena hanya lokasi yang dekat, tetapi harga yang terjangkau serta kualitas yang baik yang membuat Toko Girsa ini tidak pernah sepi pengunjung. Atas perkembangannya itu, maka Toko Girsa mulai mengembangkan fasilitas-fasilitasnya demi kenyamana konsumen, seperti menjual minuman dingin serta pengadaan pendingin ruangan. Sehingga para konsumen merasa nyaman ketika berada di Toko Girsa ini.

\section{Tabel 1.Data Mesin Canon IR 6070}

\begin{tabular}{|c|c|}
\hline Merk Mesin & Canon IR 6070 \\
\hline Metode Penyusutan & Straight Line \\
\hline Harga Beli & $\operatorname{Rp} 23.000 .000$ \\
\hline Masa Manfaat & 10 Tahun \\
\hline Tahun Pembelian & 2010 \\
\hline Nilai Residu/ Nilai Sisa 10 Tahun kemudian & 0 \\
\hline Nilai Buku April 2015 & Rp 15.000 .000 \\
\hline $\begin{array}{l}\text { Total Biaya Pemeliharaan April } 2014 \text { s/d } \\
\text { April } 2015\end{array}$ & $\operatorname{Rp} 6.000 .000$ \\
\hline $\begin{array}{c}\text { Rata-Rata Produksi Fotokopi Setiap } \\
\text { Bulannya }\end{array}$ & 30.000 lembar \\
\hline Biaya kertas, tinta dan listrik per bulan & $\begin{array}{c}\operatorname{Rp} 1.950 .000 \\
(\operatorname{Rp} 1.800 .000+\operatorname{Rp} 50.000+\operatorname{Rp} 100.000)\end{array}$ \\
\hline Pendapatan per bulan & $\begin{array}{c}\operatorname{Rp} 6.000 .000 \\
(\mathrm{Rp} .200 \times 30.000)\end{array}$ \\
\hline Laba Bersih per bulan & $\begin{array}{c}\operatorname{Rp} 4.050 .000 \\
(\operatorname{Rp} 6.000 .000-\operatorname{Rp} 1.950 .000)\end{array}$ \\
\hline
\end{tabular}

Sumber : Toko Girsa 2015

Mesin fotokopi yang dimiliki oleh Toko Girsa adalah Canon IR 6070 yang dibeli pada tahun 2010 dengan harga Rp 23.000.000. Mesin tersebut terhitung sampai pada tahun 2015 sudah mencapai 5 tahun masa manfaat pemakaian dengan rata-rata dapat mencetak sebanyak 1000 lembar copy-an perharinya. Jika dihitung mesin ini memberikan keuntungan pada Toko Girsa sebanyak Rp 4.150.000 per bulannya, dan jika dihitung per tahun adalah sebesar Rp 49.800.000. Sisa manfaat pemakaian mesin ini adalah 5 tahun.

Tabel 2.Rincian Biaya Pemeliharaan Mesin Per Bulan hingga Per tahun

\begin{tabular}{|l|r|r|}
\hline \multicolumn{1}{|c|}{ Biaya Pemeliharaan Mesin } & \multicolumn{1}{c|}{ Per bulan } & \multicolumn{1}{c|}{ Per tahun } \\
\hline Biaya roll pemanas & 100,000 & $1,200,000$ \\
\hline Biaya web & 100,000 & $1,200,000$ \\
\hline Biaya cleaning web & 100,000 & $1,200,000$ \\
\hline Biaya magnet roll & 100,000 & $1,200,000$ \\
\hline Biaya Perbaikan Lain-lain & 100,000 & $1,200,000$ \\
\hline Total & $\mathbf{5 0 0 , 0 0 0}$ & $\mathbf{6 , 0 0 0 , 0 0 0}$ \\
\hline
\end{tabular}

Sumber : Toko Girsa 2015 
Total biaya yang harus dikeluarkan untuk pemeliharaan mesin fotokopi sebesar Rp. 500,000. Adapun total biaya selama setahun sebesar Rp. 6,000,000, data di atas ini menunujukkan biaya pemeliharan mesin baru maupun lama.

\section{Pembahasan}

Berdasarkan hasil penelitian di atas, dimana peneliti melakuna penelitian pada sebuah mesin yang dimilki Toko Girsa, menjadi sesuatu yang sangat penting dalam pembahasan ini yaitu mengenai penerapan konsep sunk cost terhadap keputusan pembelian aktiva tetap yang ada pada Toko Girsa.

Untuk mencapai keuntungan yang maksimum tiap harinya, Toko Girsa membutuhkan mesin fotokopinya dalam keadaan prima setiap saat. Untuk itu, perusahaan harus selalu memperhatikan segi perawatan dari setiap mesinnya. Karena jika terjadi gangguan atau kerusakan, mesin tersebut tidak dapat beroperasi yang tentunya dapat menurunkan pendapatan dari perusahaan.

Tapi ada beberapa hal yang harus diperhatikan oleh perusahaan salah satunya adalah masalah biaya. Untuk mendapatkan kondisi mesin yang selalu prima setiap saat, tentunya terdapat biaya-biaya ynag harus dikeluarkan oleh perusahaan, yaitu biaya pemeliharaan mesin tersebut. Maka dari itu untuk meminimalisir kerugian yang akan di tanggung oleh Toko Girsa yang dalam hal ini perusahaan memiliki banyak mesin dan membutuhkan perawatan yang tidak sedikit, maupun harus mengganti dengan mesin yang baru dengan harga yang lebih mahal, tentunya perusahaan harus mempunyai strategi.

Banyak metode biaya yang ditimbulkan untuk membantu manajer dalam pengambilan keputusan. Salah satu biaya yang disebut sunk cost, Sunk cost adalah biaya yang terjadi di masa lalu dan tidak dapat diubah sekarang maupun dimasa mendatang. Sunk cost seringkali mempengaruhi keputusan seorang manajer perusahaan untuk mengambil keputusan yang tepat. Salah satunya adalah keputusan dalam hal pembiayaan aktiva tetap yang dimiliki oleh perusahaan. Oleh karena itu, menjadi tanggung jawab manajer perusahaan untuk dapat mengevaluasi informasi akuntansi yang relevan dalam setiap pengambilan keputusan.

Apabila di hitung kembali maka sunk cost dari mesin fotokopi Canon IR 6070 pada Toko Girsa adalah sebagai berikut :

Sunk Cost

$$
\begin{aligned}
& =\text { fixed cost }- \text { avoidable fixed cost } \\
& =\operatorname{Rp} 15.000 .000-\operatorname{Rp} 6.000 .000 \\
& =\operatorname{Rp} 9.000 .000
\end{aligned}
$$

Dari hasil perhitungan penyusutan dan nilai buku di atas, maka dapat diketahui sunk cost mesin fotokopi Canon IR 6070 tersebut. Dimana subk cost diperoleh dari hasil penguragan antar fixed cost dan avoidable fixed cost. Fixed cost adalah biaya yang dikeluarkan oleh suatu perusahaan yang jumlahnya tidak tergantung dengan barang atau jasa yang diproduksi oleh perusahaan tersebut. Sedangkan avoidable fixed cost adalah biaya tetap yang penggunaannya dapat dihindari. Jadi fixed cost merupakan nilai buku dari mesin fotokopi Canon IR 6070 dan avoidable fixed cost adalah total pemeliharaan mesin tersebut, yang kurang lebih telah beropersai selama 5 tahun lamanya. Maka sunk cost dari mesin fotokopi Canon IR 6070 adalah Rp 9.000.000.

Jika melihat hasil perhitungan di atas, maka Toko Girsa akan rugi jika menjual mesin fotokopinya. Karena mesin fotokopi Canon IR 6070 ini masih dapat mengasilkan keuntungan sebesar Rp 49.800 .000 per tahun dengan sunk cost (biaya terpendam yang tidak dapat dikembalikan lagi) adalah sebesar Rp 9.000.000. oleh karena itu Toko Girsa sebaiknya mempertahankan mesin fotokopinya dari pada mengganti dengan mesin fotokopi yang baru. Karena dengan perawatan yang rutin, mesin fotokopi yang sudah lama pun masih dapat memberikan keuntungan yang maksimal bagi perusahaan.

Jadi dapat dilihat konsep sunk cost pada Toko Girsa dapat diterapkan, tetapi tidak dapat dijadikan sebagai dasar pengambilan keputusan penggantian mesin yang baru, karena dalam mempertahakan atau mengganti mesin yang baru, kerugian atau sunk cost pada mesin tersebut tetap akan ada dan tidak akan hilang ketika perusahaan mengambil keputusan untuk mengganti mesin yang lama dengan mesin yang baru. 


\section{PENUTUP}

\section{Kesimpulan}

Perhitungan sunk cost pada mesin fotokopi Canon IR 6070 pada Toko Girsa lebih kecil, yang artinya output pertahun dari mesin ini jauh lebih besar dari biaya yang dikeluarkan. Penerapan konsep sunk cost pada mesin fotokopi Canon IR 6070 pada Toko Girsa tidak dapat dipakai sebagai dasar pengambilan keputusan pemilik peruahaan, karena sunk cost merupakan timbu pada masa lalu yang tidak akan mempengaruhi pengambilan keputusan pada saat ini. Oleh karena itu biaya ini juga disebut biaya tidak relevan (irrelevant cost).

Saran

Toko Girsa tidak dapat menggunakan konsep Sunk Cost sebagai dasar untuk pengambilan keputusan dalam membeli atau memertahankan mesin fotokopinya. Semuanya kembali kepada pemilik perusahaan yang dapat menilai apakah mesin fotokopinya masih layak dipertahankan, ataukah sudah harus diganti dengan mesin yang baru.

\section{DAFTAR PUSTAKA}

Anwar, Ashari dan Indrayenti. 2010. Harga Pokok Produksi Dalam Kaitannya Dengan Penentuan Harga Jual Untuk Pencapaian Target Laba Analisis Studi kasus Pada PT. Indra Brother's di Bandar Lampung. http://jurnal.ubl.ac.id/index.php/jak/article/download/10/9. di akses. 21/09/14

Devi, Diana Rani. 2012. Rancangan Biaya Diferensial Dalam Pengambilan Keputusan Menerima Atau Menolak $\begin{array}{llllll}\text { Pesanan } & \text { Khusus } & \text { Pada } & \text { Zodiak } & \text { Sidoarjo. }\end{array}$ http://ebook.library.perbanas.ac.id/6674_ARTIKEL\%20ILMIAH.pdf. Di akses 21/09/14

Halim, Abdul., Bambang, Supomo., Kusufi, Muhammad. 2013. Akuntansi Manajemen Edisi ke Dua. BPFE, Yogyakarta.

L.M. samryn, SE., Ak., M.M, 2012. Akuntansi Manajemen : Informasi Biaya Untuk Mengendalikan Aktivitas Operasi dan Informasi. Edisi Pertama. Penerbit : Kencana, Jakarta

Mulyadi, 2011. Akuntansi Manajemen. Edisi ketiga. Penerbit : Salemba Empat

Mulyadi, 2014. Akuntansi Biaya. Edisi kelima. Penerbit : YKPN, Yogyakarta

Siegel, Joel G and Shim, Jae K. 2000. Kamus Istilah Akuntansi. Elex Media Komputindo, Jakarta.

Simamora Henry., 2012. Akuntansi Manajemen. Edisi III. Star Gate Publisher, Duri. Riau.

Wasilah dan Sri Nurhayanti. 2014. Akuntansi Syariah di Indonesia. Edisi III. Salemba Empat, Jakarta 